\title{
Yield Performance of Improved Tomato (Lycopersiconesculentum Mill.) Varieties at West Shoa Zone, Ethiopia
}

\author{
Chala Begna Bedassa, Bikila Olika Fufa, Mosisa Chewaka Aga* \\ Department of Horticulture, Ambo University, Ambo, Ethiopia \\ Email address: \\ agamosisa@gmail.com (M. C. Aga) \\ ${ }^{*}$ Corresponding author \\ To cite this article: \\ Chala Begna Bedassa, Bikila Olika Fufa, Mosisa Chewaka Aga. Yield Performance of Improved Tomato (Lycopersiconesculentum Mill.) \\ Varieties at West Shoa Zone, Ethiopia. Advances in Bioscience and Bioengineering. Vol. 8, No. 1, 2020, pp. 1-5. \\ doi: $10.11648 /$ j.abb.20200801.11
}

Received: September 24, 2019; Accepted: November 4, 2019; Published: April 14, 2020

\begin{abstract}
Tomato (Lycopersiconesculentu Mill.) belongs to the family Solanaceae and is one of the most popular, important edible and nutritious vegetable crops in the world. Most parts of the world produce and consume tomato from the home gardens and greenhouse to the larger commercial farms as it is able to various agro ecological conditions. The promising growth performance and high yield of tomato depends on the selection of appropriate varieties for a particular location. A field experiment with the objective of evaluating the adaptability and yield performance of improved tomato varieties was conducted at Ambo and Toke kutaye districts of west Shoa zone during 2017 and 2018 growing seasons. Six tomato varieties namely Cochoro, Fetan, Chali, Melka shola, ARP tomato d2 and Melka salsa were evaluated for adaptability and yield performance. Data were recorded on growth and yield contributing parameters like plant height, canopy diameter, and primary branches plant ${ }^{-1}$, number of cluster plant ${ }^{-1}$, number of fruits cluster $^{-1}$, unmarketable and marketable yield. The study showed that there was difference in growth and yield of tomato among different varieties while non-significant result was observed between the two locations. After two years evaluation, the longest plant height $(50.7 \mathrm{~cm})$, number of primary branches $(10.84)$, number of cluster plant ${ }^{-1}$ (17.92), number of fruit cluster $^{-1}$ (32.6), and marketable yield (27.12 ton ha ${ }^{-1}$ ) were recorded in tomato variety ARP tomato d2 at Ambo and Toke Kutayedistricts. Therefore, variety ARP tomato $\mathrm{d} 2$ is promising variety in providing high yield for the test sites.
\end{abstract}

Keywords: Adaptation, Tomato, Variety, Yield Performance

\section{Introduction}

Tomato (Lycopersiconesculentu Mill.) belongs to the family Solanaceae and is one of the most popular, important edible and nutritious vegetable crops in the world [1]. The Central and South America are believed to be the origin of the crop. It became distributed to Europe and Asia in the early and mid-1960s. The crop spread via traders to Egypt, Sudan, South Africa, West Africa and to the rest of the world [2]. Like other vegetable crops, tomato is vital sources of carbohydrates, minerals, sugars, amino acids, vitamins (especially vitamin B and C), Phosphorus and dietary fibers [3]. Most parts of the world produce and consume tomato from the home gardens and greenhouse to the larger commercial farms as it is able to various agro ecological conditions [4]. With respect to world vegetables production, tomato ranks third next to potato and sweet potato [5]. China is the world's leading producer of tomato with the annual production of more than 30 million tons and followed by United States, India, Turkey, Egypt, and Italy, respectively [6].

In Ethiopia tomato can be consumed in raw, ingredient in many dishes, salads, sauces and drinks. It is an important ingredient of diet for the majority of people in almost every household. It is also among the most economically important vegetable crop [7]. The total production and productivity in Ethiopia however is far below than the world and major African producers. The area coverage by tomato in 2015 was 
around 5000 ha with the production of 40 tones and productivity of 6 ton $\mathrm{ha}^{-1}$ that is far below average world production and productivity [8]. Tomato is widely grown vegetable crop in Ethiopia. The total production of tomato in the Ethiopia has shown a marked increase recently, indicating that it became the most profitable crop providing a higher income to small-scale farmers compared to other vegetable beside the low production and productivity [9].

Tomato is an annual plant which can grow to up to more than two meter in which the first harvest can possible after one month and half of flowering or three to four month after sowing [10]. Though adapted to wider agro eco climate conditions, tomato prefer temperature of $20-27^{\circ} \mathrm{C}$ for better fruit setting and yield and when the temperature go more than $30^{\circ} \mathrm{C}$ or fall below $10^{\circ} \mathrm{C}$ fruit setting is very poor [11]. Likewise, researches in the early study stated, deep well drained sandy loam soil with the $\mathrm{pH}$ of 6-7 is better for production of Tomato [12]. Currently there are progresses in increasing tomato production at global level. However, around half of majority of developing countries like Ethiopia does not have an access to adequate tomato supplies. Among many different contributing factors for the low yield and poor quality tomato product, lack of improved variety that is adapted to growing condition and poor management practices [13].

The success of vegetables production in general and tomato in particular is mainly dependent up on the selection of appropriate varieties for a particular location. In the last few decades several high yielding varieties and hybrids have been developed and recommended by different Agricultural research centers in Ethiopia. However, the yield potential, Productivity and quality need to be tested under various agro ecology and climatic conditions. Therefore, the objective of this study was to evaluate improved tomato varieties for their adaptability and yield performance in Ambo and Toke Kutaye districts, west Shoa zone, Oromia regional state.

\section{Materials and Methods}

\subsection{Study Area}

The current field experiment was conducted at two locations of west Shoa zones; Ambo and Toke Kutaye districts for two consecutive years. The experiment was carried out during 2017 and 2018 years in the dry season using furrows irrigation method. Ambo is located at latitude of $8^{\circ} 59^{\prime} \mathrm{N}$ and longitude $37^{\circ} 51^{\prime} \mathrm{E}$. and an elevation of 2101 m.a.s.l. and Toke Kutaye is located at the altitude of between 1900 and 3100 m.a.s.l, with $8^{\circ} 58^{\prime}$ to $8.97^{\circ} \mathrm{N}$ latitude and 37046 'to $380^{\prime} \mathrm{E}$ longitude The two areas receive heavy rain from onset of July to the end of August. The annual rainfall ranges from $1000-1588.06 \mathrm{~mm}$ and the temperature of the district ranged between $9.44^{\circ} \mathrm{C}$ and $21.86^{\circ} \mathrm{C}$ with average of $15.65^{\circ} \mathrm{C}$. The physical and chemical properties soil in the study area is characterized as vertisols with light red in color, clay loam in texture and $\mathrm{pH}$ value of $6.8[14,15]$.

\subsection{Methodology}

Nationally releasedsix improved tomato varieties namely, Cochoro, Fetan, Chali, Melka shola, ARP Tomato d2 and Melka salsa were obtained from Melkassa Agriculture research center were used for both Ambo and Toke Kutaye field experiment. The descriptions of these varieties were presented in table 1 . In both experimental locations, the treatments were arranged in a Randomized Complete Block Design (RCBD) with four replications. Seedlings were raised in nursery beds and the undamaged and uniform mediumsized seedlings were carefully transplanted after 6 weeks to the experimental plots of $2 \mathrm{~m} \times 3 \mathrm{~m}$ dimensions at a spacing of $70 \mathrm{~cm} \times 30 \mathrm{~cm}$ between rows and plants, respectively. The spacing between two plots in each replication and between adjacent blocks was $0.5 \mathrm{~m} \times 1 \mathrm{~m}$, respectively. All agronomic managements were practiced following the recommendation [2].

Table 1. Description of Tomato Varieties Used For the Experiment.

\begin{tabular}{|c|c|c|c|c|c|c|c|}
\hline Variety & $\begin{array}{l}\text { Growth } \\
\text { habit }\end{array}$ & $\begin{array}{l}\text { Maturity } \\
\text { days }\end{array}$ & Fruit shape & $\begin{array}{l}\text { Average fruit } \\
\text { weight (gm) }\end{array}$ & $\begin{array}{l}\text { Average } \\
\text { yield (q/ha) }\end{array}$ & $\begin{array}{l}\text { year of } \\
\text { release }\end{array}$ & Purpose \\
\hline ARP Tomato $\mathrm{d} 2$ & Determinate & $75-80$ & Cylindrical & ----- & 395 & 2012 & fresh market \\
\hline Fetan & Determinate & $75-80$ & Cylindrical & $110-120$ & 454 & 2005 & fresh market \\
\hline Chali & Determinate & $85-100$ & Square & $80-90$ & 430 & 2007 & Processing \&fresh market \\
\hline Cochoro & Determinate & $85-90$ & Square & $70-80$ & 463 & 2007 & Processing \&fresh market \\
\hline Melka Shola & Determinate & $100-120$ & Cylindrical & $70-80$ & 430 & 1998 & Processing \&fresh market \\
\hline Melka Salsa & Determinate & $100-110$ & Pear & $40-50$ & 150 & 1998 & Processing \&fresh market \\
\hline
\end{tabular}

Source: [16].

\subsection{Data Collection}

Six randomly selected plants were used from the central three rows for all treatment prior to flowering to record quantitative data measurements such as: plant height $(\mathrm{cm})$, number of primary branches (No.), number of fruit cluster per plant (No.), number of fruit per cluster (No.), marketable yield and unmarketable yield ( $\mathrm{g}$ plot-1, then later converted to ton per hectare).

\subsection{Data Analysis}

The data recorded were subjected to analysis of variance (ANOVA) using SAS statistical software. The significant difference between the means was tested using LSD at 5\% level of significance. T-test was used to compare the yields of the crops on the two locations. 


\section{Result and Discussion}

\subsection{Growth Parameters}

\subsubsection{Plant Height}

There was no significance difference between the two growing locations in plant height. ARP tomato $\mathrm{d} 2$ was the tallest variety followed by Fetan. Both varieties were however statistically similar in their plant height. On the other hand Melka salsa was found to be the shortest variety among the six tested varieties. The mean value of plant height ranges between $31.79 \mathrm{~cm}$ and $50.70 \mathrm{~cm}$ (Figure 1). These results coincide with the findings of different researchers, who reported differences in plant height among cultivars/hybrids of tomato put under evaluation and screening trials $[17,18]$. The tallness, shortness and other morphological differences are varietal characteristics, which are controlled and expressed by certain genes. Similarly in line with the observations of earlier finding who found that the heights of tomato plants vary from Varity to variety [1]. The tallest tomato varieties usually require longer duration of growth period and special management practices such as stalking. On the other hand the short varieties may not need stalking and their production may require less labor expense that makes them highly popular for commercial cultivation in tropical conditions [19].

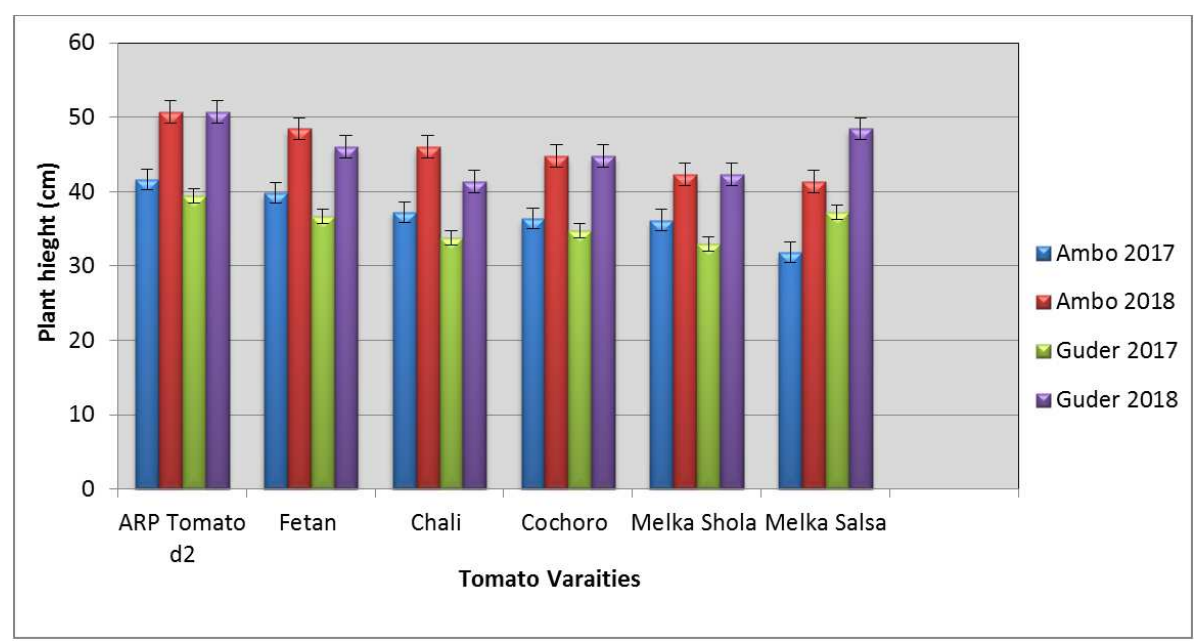

Figure 1. Response of varieties on plant height over the two years in Ambo and Toke Kutaye, West Shoa, Ethiopia. Error bars indicate mean +/- standard error (SE).

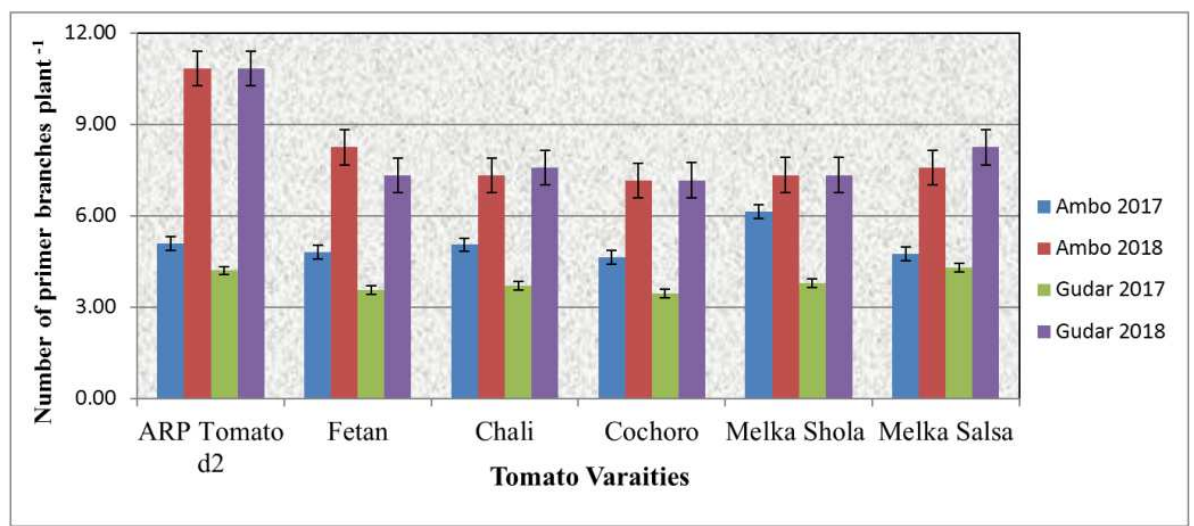

Figure 2. Number of primer branches per plant as affected by different varieties. Error bars indicate mean $+/-S E$.

\subsubsection{Number of Primary Branches}

The number of primary branches per plant was counted because is an important parameter which indicates the yielding capacity of tomato variety. As result the highest number of primary branches per plant (10.84) was recorded for variety ARP tomato $\mathrm{d} 2$. The least number of primary branches numbers (3.45) was recorded for variety Cochoro (Figure 2). There was significance difference $(\mathrm{p}<0.05)$ in primary branches number per plant among tomato varieties and growing seasons, while there was no significance difference between the two experimental sites. The highest primary branch number for all varieties recorded in the second growing year. The variation in branches number per season may be related to the optimum weather conditions recorded in the second growing year. The results of this study agree with the findings of previous study, who reported that there is considerable difference in number of branches among tomato cultivars and an increasing trend in the number of primer branches with an increase in plant height [20]. Furthermore the results are in line with the observations of early studies who reported the primary branches of tomato ranges from 3.1 to 12.6 per plant [21]. On the other hand, varieties with highest number of primary braches in this study gave highest yield for ARP tomato $\mathrm{d} 2$ Varity which is 
probably associated with the increased number of branches will results more number of fruit setting.

\subsection{Yield and Yield Related Traits}

\subsubsection{Number of Clusters per Plant}

The result of the current study showed that number of fruit cluster per plant significantly $(\mathrm{p}<0.05)$ differed among tomato varieties. On the other hand, there was no significance difference in tomato fruit cluster per plant between the two growing places. There was also no significant difference between varieties in fruit cluster per plant in the first and second growing season (Table 2). At the two growing condition and growing season, variety ARP tomato $\mathrm{d} 2$ showed the largest number of cluster per plant among tested tomato varieties. Variety ARP Tomato d2 produced the highest (17.92) followed by variety Melka salsa (14.58) while the lowest fruit cluster (7.88) was produced by variety Melka shola (Table 2). As the number of cluster per plant is one of the indicators for number of fruit per plant, it is an important criterion to select promising variety for the yield. In the current study, the number of cluster per plant directly proportional with plant height and primary branches per plant. Therefore, the highest number of cluster produced by ARP tomato $\mathrm{d} 2$ may be due to vigorous growth habit that will be related to genetic variability among tomato varieties. The current result is in line with the finding of previous researcher who evaluated eleven tomato varieties for their adaptability and found different number of fruit cluster per plant among tomato varieties [22]. Similar result was also observed, while studying yield and fruit qualities of tomato varieties and got significantly different fruit cluster per plant among tomato varieties [13].

The highest number of fruit cluster ${ }^{-1}$ (32.60) and (10.25) followed by (27.70) and (10.25) presented in Table 2 were recorded in tomato variety ARP tomato $\mathrm{d} 2$ and melka salsa at Ambo and Toke kutaye respectively in the first growing conditions. The results are in accordance with early findings in which eleven tomato varieties tested for their adaptability and got variation in fruit cluster ${ }^{-1}$ among varieties [22]. Likewise another study also found variation in number of fruit $^{-1}$ among different tomato varieties [23].

Table 2. Average number of cluster per plant and number of fruit per cluster of tomato varieties under Ambo and TokeKutaye Districts during thetwo growing seasons.

\begin{tabular}{|c|c|c|c|c|c|c|c|c|}
\hline \multirow{3}{*}{ Varieties } & \multicolumn{4}{|c|}{ Number of Fruits Cluster ${ }^{-1}$} & \multicolumn{4}{|c|}{ Number of Clusters Plant $^{-1}$} \\
\hline & \multicolumn{2}{|c|}{ Ambo } & \multicolumn{2}{|c|}{ Toke Kutaye } & \multicolumn{2}{|c|}{ Ambo } & \multicolumn{2}{|c|}{ Toke Kutaye } \\
\hline & 2017 & 218 & 2017 & 2018 & 2017 & 2018 & 2017 & 2018 \\
\hline ARP Tomato $\mathrm{d} 2$ & $32.60^{\mathrm{a}}$ & $4.50^{\mathrm{a}}$ & $0.25^{\mathrm{a}}$ & $4.50^{\mathrm{a}}$ & $16.70^{\mathrm{a}}$ & $17.92^{\mathrm{a}}$ & $13.25^{\mathrm{ab}}$ & $17.92^{\mathrm{a}}$ \\
\hline Fetan & $12.87^{\mathrm{b}}$ & $4.58^{\mathrm{a}}$ & $7.25^{\mathrm{bc}}$ & $2.75^{\mathrm{b}}$ & $8.49^{c}$ & $14.58^{\mathrm{ab}}$ & $7.00^{\mathrm{c}}$ & $8.42^{\mathrm{c}}$ \\
\hline Chali & $13.85^{\mathrm{b}}$ & $2.75^{\mathrm{b}}$ & $8.75^{\mathrm{ab}}$ & $2.95^{\mathrm{b}}$ & $8.58^{\mathrm{c}}$ & $8.42^{\mathrm{c}}$ & $8.75^{\mathrm{c}}$ & $11.58^{\mathrm{bc}}$ \\
\hline Cochoro & $13.61^{\mathrm{b}}$ & $3.25^{\mathrm{b}}$ & $6.75^{\mathrm{c}}$ & $3.25^{\mathrm{b}}$ & $9.92^{\mathrm{bc}}$ & $8.25^{\mathrm{c}}$ & $9.50^{\mathrm{bc}}$ & $8.25^{\mathrm{c}}$ \\
\hline Melka Shola & $12.65^{\mathrm{b}}$ & $3.06^{\mathrm{b}}$ & $7.50^{\mathrm{bc}}$ & $3.06^{\mathrm{b}}$ & $7.88^{\mathrm{c}}$ & $8.50^{\mathrm{c}}$ & $8.75^{\mathrm{c}}$ & $8.50^{\mathrm{c}}$ \\
\hline $\operatorname{LSD}(5 \%)$ & 8.76 & 0.99 & 1.85 & 1 & 4.19 & 3.74 & 4.06 & 3.74 \\
\hline CV (\%) & 14.52 & 19.24 & 14.52 & 19.24 & 25.85 & 21.93 & 25.86 & 21.94 \\
\hline
\end{tabular}

The means followed by the same letter within the same column are not significantly different at $5 \%$ level of significance

\subsubsection{Marketable and Unmarketable Yield}

Tomato varieties showed significant variation $(\mathrm{p}<0.05)$ in the average marketable yield at both sites (Table 3 ). However, there were no significant differences between yields from different sites. The higher yields were recorded in the second growing season at both experimental sites that will be attributed by plant height number of cluster per plant and fruit cluster $^{-1}$. The highest marketable yield (27.12 ton $\mathrm{ha}^{-1}$ ) was recorded in tomato variety ARP tomato $\mathrm{d} 2$ at Ambo during the second growing season while the same variety produced $\left(22.88\right.$ ton $\left.\mathrm{ha}^{-1}\right)$ at Toke kutaye site in the second growing season (Table 3). There was no significant difference between the two sites in the marketable yields. Similar result was obtained, by studying yield and fruit qualities of tomato varieties and got significantly different yield among different tomato varieties [13]. The early studies also found different tomato yield among different varieties in studying the adaptability of tomato varieties [22].

Table 3. Average value of Marketable and unmarketable yield of Tomato varieties under two growing condition in the two growing seasons.

\begin{tabular}{|c|c|c|c|c|c|c|c|c|}
\hline \multirow{3}{*}{ Varieties } & \multicolumn{4}{|c|}{ Unmarketable Yield plot ha ${ }^{-1}$} & \multicolumn{4}{|c|}{ Marketable Yield toneha ${ }^{-1}$} \\
\hline & \multicolumn{2}{|l|}{ Ambo } & \multicolumn{2}{|c|}{ Toke Kutaye } & \multicolumn{2}{|c|}{ Ambo } & \multicolumn{2}{|c|}{ Toke Kutaye } \\
\hline & 2017 & 2018 & 2017 & 2018 & 2017 & 2018 & 2017 & 2018 \\
\hline ARP Tomato $\mathrm{d} 2$ & $27.58^{\mathrm{a}}$ & $11.42^{\mathrm{b}}$ & $33.33^{\mathrm{ab}}$ & $11.42^{\mathrm{b}}$ & $13.58^{\mathrm{a}}$ & $27.12^{\mathrm{a}}$ & $7.08^{\mathrm{a}}$ & $22.88^{\mathrm{a}}$ \\
\hline Fetan & $19.37^{\mathrm{a}}$ & $16.12^{\mathrm{ab}}$ & $30.00^{\mathrm{ab}}$ & $20.22^{\mathrm{ab}}$ & $3.95^{\mathrm{b}}$ & $15.00^{\mathrm{c}}$ & $2.83^{\mathrm{b}}$ & $15.8 b^{c}$ \\
\hline Chali & $16.25^{\mathrm{a}}$ & $20.20^{\mathrm{ab}}$ & $21.25^{\mathrm{b}}$ & $11.97^{\mathrm{ab}}$ & $7.12^{\mathrm{b}}$ & $21.50^{\mathrm{b}}$ & $3.38^{\mathrm{b}}$ & $12.12^{\mathrm{c}}$ \\
\hline Cochoro & $19.50^{\mathrm{a}}$ & $17.17^{\mathrm{ab}}$ & $22.08^{\mathrm{ab}}$ & $17.17^{\mathrm{ab}}$ & $4.28^{\mathrm{b}}$ & $21.07^{\mathrm{b}}$ & $1.68^{\mathrm{b}}$ & $12.28^{\mathrm{c}}$ \\
\hline Melka Shola & $17.97^{\mathrm{a}}$ & $20.70^{\mathrm{a}}$ & $25.00^{\mathrm{ab}}$ & $20.72^{\mathrm{a}}$ & $4.83^{b}$ & $14.50^{\mathrm{c}}$ & $2.97^{\mathrm{b}}$ & $12.8 b^{c}$ \\
\hline $\operatorname{LSD}(5 \%)$ & 8.62 & 5.31 & 10.52 & 5.31 & 2.57 & 3.29 & 1.59 & 3.57 \\
\hline $\mathrm{CV}(\%)$ & 40.74 & 35.78 & 40.74 & 35.79 & 43.40 & 25.31 & 43.39 & 25.32 \\
\hline
\end{tabular}

The means followed by the same letter within the same column are not significantly different at $5 \%$ level of significance. 


\section{Conclusion and Recommendation}

Tomato is one of the most popular, important edible and nutritious vegetable crops in the world. Like in most parts of the world it is produced and consumed in Ethiopia. The current study was conducted to evaluate the performance of improved tomato varieties for their adaptability and yield potential in Ambo and Toke Kutaye districts of west Shoazone, Oromia regional state, Ethiopia. From the current study it is concluded that tomato variety ARP tomato $\mathrm{d} 2$ performed better in growth and yield at both experimental sites among tested varieties. There was no difference in yield between two growing sites, which may be attributed by proximity of the two sites. Therefore, variety ARP tomato $\mathrm{d} 2$ is promising variety is providing high yield for the test sites.

\section{Acknowledgements}

The Authors acknowledge Ambo University for financing the experiment and Melkassa Agriculture research center for provision of the tomato varieties. All authors of reference materials used in the paper are acknowledged.

\section{Conflict of Interests}

All authors do not have any possible conflicts of interest.

\section{References}

[1] Meseret, D., Ali, M., \& Kassahun, B. (2012). Evaluation of Tomato (Lycopersiconesculentum Mill.) Genotypes for Yield and Yield Components. The African Journal of Plant Science and Biotechnology, 6 (special issue 1), 45-49.

[2] Asfaw, Z. and Eshetu, D. 2015. Production and management of major vegetable crops in Ethiopia, December 2015, Addis Ababa, Ethiopia. Ethiopian Institute of Agricultaral Research, Addis Ababa, Ethiopia; KOPIA Ethiopia Centre, Addis Ababa, Ethiopia. Printed at Eth-Cana Press 149 pages Addis Ababa, Ethiopia. ISBN: 978-99944-66-25-2.

[3] Naika, S., J. V. L. de Jeude, M. de Goffau, M. Hilmi and B. V. Dam. 2000. Cultivation of tomato. Production, processing and marketing, Agromisa/CTA. Revised edition.

[4] Agyeman., K, I. Osei-Bosu, J. N. Berchie, M. K. Osei, M. B. Mochiah, J. N. Lamptey, O. Kingsley and G. Arku. 2012. Effect of poultry manure and different combinations of inorganic fertilizers on growth and yield of four tomato varieties in Ghana, Agric. Sci. J, 2 (4): 27-34.

[5] FAO, 2006. FAO Production Yearbook, Basic data Unit, Statistics Division, FAO, Rome, Italy, No. 55, pp 125-127.

[6] FAOSTAT, 2010. Food and Agriculture Organization of the United Nations. Available http://faostat.fao.org. Accessed July/ 26/2011.

[7] Kitila M., Belew D., Mohammed A., and Getachew Y., 2012. Effect of intra-row spacing and variety on fruit yield and quality of fresh market tomato (Lycopersiconesculentum Mill.) under Jimma condition, Ethiopia. Ethiop. J. Appl. Sci. Technol. Vol. 3 (1): 32-42.

[8] FAOSTAT. 2011. Statistical Database of the Food and Agriculture of the United Nations. FAO, Rome, Italy. (http://faostat.fao.org/site/612/default.aspx\#ancor).

[9] Lemma D. 2003. Tomatoes Research Experience and Production Prospects. Research Report No. 43. Ethiopian Agricultural Research Organization, Addis Ababa, 1 (33): 46.

[10] Iqbal, M., M. Niamatullah, I. Yousaf, M. Munir and M. Z. Khan. 2012. Effect of nitrogen and potassium on growth, economical yield components of tomato. Sarhad J. Agric, 27 (4): $545-548$.

[11] Hanson, P., J. T. Chen, C. G. Kuo, R. Morris and R. T. Opena. 2000. Suggested cultural practices for tomato. International cooperator Guide.

[12] Patel, J. S, Sitapara, H. H, Patel K. A. Influence of plant growth regulators on growth, yield and quality of tomatoand brinjal. International Journal of Forestry and Crop Improvement. 2012; 3 (2): 116-118

[13] Yeshiwas, Y, Belew, D, and Tolessa, K., 2016. Tomato (Solanumlycopersicum L.) Yield and Fruit Quality Attributes as Affected by Varieties and Growth Conditions, World J. of Agri. Sci. 12 (6): 404-408.

[14] Asnakew W., 1988. Physical Properties of Ethiopian VertisolsIn Management of Sub-Saharan Africa (eds. Jutzi, S. C., Haque, I., Mclntire, J. and Stares, J. E. S.). Pp. 111-123.

[15] Balemi, T. (2015). Effect of integrated use of cattle manure and inorganic fertilizers on tuber yield of potato in Ethiopia Effect of integrated use of cattle manure and inorganic fertilizers on tuber yield of potato in Ethiopia. Journal of Soil Science and Plant Nutrition, 12 (2), 253-261. https://doi.org/10.4067/S0718-95162012000200005

[16] MOA 1998-2014. Crop Variety Registry. Animal and plant Health Regulatory Directorate. Issue No. 3-17. Addis Ababa, Ethiopia

[17] Kallo, G., Chaurasia, S. N. G., Major, S. and Singh, M. 1998. Stability analysis in tomato. Vegetable Science 25 (1): 81-84.

[18] Manoj, R. and Raghav, M. 1998. Performance of F1 hybrids and high yielding varieties of tomato under mid-west plains of Uttar Pradesh. Progressive Horticulture 30 (3): 194-197.

[19] Naika, S., de Jeude, J. V. L., de Goffau, M., Hilmi, M., \& van Dam, B. 2005. Cultivation of tomato. Didigrafi Publishing. Netherlands. pp. 34-57.

[20] Sharma, S. K. and K. B. Rastogi. 1993. Evaluation of some tomato cultivars for seed production under mid hill conditions of Himachal Pardesh. Annals of Agri. Res. India. 14 (4): 494-496.

[21] Fayaz, O. K, S. S, A H and S. A. (2007) Performance evaluation of tomato cultivars at high altitude. Sarhad J. Agric. Vol. 23, No. 3.

[22] Khan, Sajid, N. H. Khan, I. Hussain, Ziaullah, N. Naeem and J. Rahman. 2016. Adaptability of tomato advance lines in temperate climate. Int. J. Agric. Environ. Res., 2 (2): 156-161.

[23] El-Amin, S. M and R. B. M. Ali., 2012. Overcoming seasonality in tropics by growing tomato varieties under cooled condition. J. Agric. Sci, 3 (4): 602-607. 